\title{
Data Privacy and Banking Secrecy: Topical Issues in Commonwealth, Continental Europe and International Jurisprudence
}

\author{
By Anatoliy A. Lytvynenko*
}

Common law imposes confidentiality on the relationships between a bank employee and a depositor, debtor or any other client, similarly to many other professional legal relationships that require professional secrecy, such as patient and physician, solicitor and client, priest and penitent, school and student, as well as other interactions featuring bilateral legal relationships. Banks maintain catalogues and registers with records that display accounts and other information regarding clients' financial affairs, which are bound to be disclosed under ordinary circumstances. The common law of the United Kingdom and the United States, as well as some continental law jurisdictions, such as Switzerland, Germany, Austria and Liechtenstein, possesses a certain legacy concerning civil actions against banks for disclosing sensitive personal data, and the ensuing trials allow us a glimpse at some particularly fascinating applications of tort and contract law principles in actions regarding the disclosure of bank records. Both English (in particular, the splendid decision of Tournier v. National Provincial and Union Bank of England), and American courts adjudicated the cases on the foundation of various tort or contract law doctrines, such as a breach of expressed or implied contract, invasion of privacy and breach of confidence or duty, while some decisions were based upon a breach of statutory duty. Thus, it would be intelligible to claim that the secrecy of bank records is far from absolute and may be subjected to various qualifications, both imposed by common law and the legislature: these may involve various derogations arising from societal interest in the detection of crime or verification of public office candidates, revenue commission checks, disclosure to testator's heirs within probate proceedings and others. While these issues of data privacy within banking secrecy have been discussed often within the context of international law, their application in the practice of international human rights courts has seldom been examined.

Keywords: Bank records; Bank secrecy; Common law; Continental case law; Contract law; Data privacy; Professional confidentiality; Tort law;

\section{Introduction - Types of Personal Information Relating to Bank Records}

The common law and the legislatures of various commonwealth jurisdictions have lodged a burden of confidentiality upon various types of bilateral legal relationships, such as physician and patient, solicitor and client, and priest and penitent. ${ }^{1}$ The same could be said concerning the bank (including its employees)

\footnotetext{
${ }^{*} \mathrm{PhD}$ (Law) Student, Ivan Franko National University of Lviv, Ukraine; PhD (Law) student, Robert Gordon University of Aberdeen, Scotland, UK. E-mail: anat.lytvynenko@ gmail.com.

${ }^{1}$ The priest and penitent privilege means that a clergyman may be exempt from testifying at trial; to be considered privileged, the communications have to be obtained in the course of his professional capacity, and in some separate situations, public interest may override this privilege. See Keenan $v$.
} 
and its clients, in various roles such as a depositor or a debtor. Under ordinary circumstances, the bank has a duty ${ }^{2}$ not to divulge bank records to third parties. Bank records are comprised of sensitive personal data that may cause an adverse impact on the plaintiff when disclosed; the list of what information may be defined as "bank records" has never been set, but upon respective American case law, I may deduce it would include, savings account books, deposit slips, property lists as well as their respective attributes, income tax returns, gifts, debts, securities and bonds, cancelled checks, honorariums, employment in business entities, interest in real estate, financial interest in partnerships and other legal entities, personal information of creditors or people who sent gifts of a fixed sum of money, financial information of relatives (upon a legislative act provision), federal income tax returns, direct and indirect investments, etc. ${ }^{3}$ In continental law countries, the basic banking records contain the name of the holder, the date of commencement and closure of deposit accounts and the date of birth or similar basic personal information of the holder or a person empowered to execute operations by means of the account. ${ }^{4} \mathrm{~A}$ password is also a substantial bank record attribute, as it may preclude the bank from paying off the balance to the plaintiff, unless provided by contract (e.g. the depositor is able to prove his identity by different means). ${ }^{5}$

In various cases involving the disclosure of bank records, US courts repeatedly disposed principles of tort law and the theory of implied contract. Such cases were adjudicated upon a breach of implied contract, which was likely found to be the most favourable claim to maintain the action, ${ }^{6}$ or upon tort doctrines, such as breach of confidence, fraud and deceit ${ }^{7}$ as well as a breach of trust or duty. In reverse, the plaintiffs occasionally sued banks for non-disclosure of the financial condition of people who had received loans from others; despite courts repeatedly supporting the ruling that banks had no such duty to do this,

Gigante, 390 N.E. 2d. 1151, 1154 (1979). Most courts and commentators held that there was no priest-penitent privilege originating from common-law; according to some learned scholars, statutes of such nature are very old. See Sippel (1994) at 1131-1133. At the same time, earlier cases involving this privilege featured a stringent common law origin. See Reese (1962) at 57; Whittaker (2000) at 157-161. For a collection of cases, see 71 A.L.R. 3d 794.

${ }^{2}$ It is arguable whether this duty is of statutory or common law. However, for instance, in Peterson v. Idaho First National Bank, 367 P.2d. 284, 289-290 (1961) and Djowharzadeh v. City National Bank \& Trust Co., 646 P2d. 616, 619 (1982) it was found to be of common law.

${ }^{3}$ In Re Addonizio, 53 N.J. 107, 248 A.2d 531, 534 (1968); County of Nevada v. MacMillen, 11 Cal. 3d 662, 670 (1974); Illinois State Employee Assn. v. Walker, 57 Ill. 2d 512, 516 (1974); O'Brien v. DiGrazia, 544 F.2d 543, 545 (1976); Plante v. Gonzalez, 575 F2d. 1119, 1122 (1978); Denoncourt v. Commonwealth State Ethics Commission, 470 A.2d 945, 946 (1983).

${ }^{4}$ See II ZR 103/57 (1958) for Germany; Caisse d'épargne de Bassetcourt c. Choffat, BGE 89 II 87, 93 (1963) for Switzerland.

${ }^{5}$ See 4 Ob 506/74; HG Vienna 3R 178/73, Decision of 5 March 1974.

${ }^{6}$ See, for instance, Peterson v. Idaho First National Bank, 367 P.2d. 284, 289-290 (1961);

Milohnich v. First National Bank of Miami Springs, 224 So. 2d 759, 760-761 (1969); Graney Development Corp. v. Taksen, 92 Misc. 2d 764, 766-768 (1978); Suburban Trust Co. v. Waller, 44 Md. App. 335, 340-343 (1979); see clarification in Indiana National Bank v. Chapman, 482 N.E. 474, 480 (1985).

${ }^{7}$ Sparks v. Union Trust Company of Shelby, 124 S.E. $2 d$ 365, 367 (1962); Richfield Bank \& Trust Co. v. Sjorgen, 309 Minn. 362, 367-368 (1976). 
the knowledge of bank employees concerning fraud may give rise to an action for breach of duty. ${ }^{8}$ Some earlier cases also featured the issue of the depositor's property rights in the records, ${ }^{9}$ but in later cases the courts sometimes upheld the decree that banking records are the bank's property, ${ }^{10}$ just as a patient's health records are the hospital's property. ${ }^{11}$ The privacy claim, however, wasn't widely accepted among courts, as some chose to follow a well-established concept of a fourfold privacy tort, and adjudicate the case upon another ground, as a breach of confidence. ${ }^{12}$ It should be stated, however, that in earlier cases in Tournier-like trials in the United States, where a bank employee divulged a plaintiff's bank records to his employer, a privacy claim was found to be nonactionable, as even then most courts accepted the view that the private facts that had been unveiled must be public and not disclosed only to a limited circle of people (e.g. employers or creditors); Had the plaintiffs' counsels stated the claim upon the theory of implied contract, such as in Peterson v. Idaho First National Bank, they probably could have succeeded. ${ }^{13}$ Unfortunately, quite a few commentators have discussed the application of tort and contract law principles in regard to civil actions involving allegedly unjustified and wrongful disclosure of the plaintiff's bank records to third parties. ${ }^{14}$ While some papers on the subject have associated the issue of banking confidentiality to various legislative acts, claiming the scope and derogations of confidence depend entirely upon the state legislation, ${ }^{15}$ in this paper I will attempt to develop a stringently case law approach towards the issue.

\section{Brief History}

The history of data privacy within the context of banking records is somewhat murky, as there is no uniform source of commentators concerning its routes, origin and duration, just as, for instance, there is no single accepted uniform view on which confidentiality privilege is more longstanding. ${ }^{16}$ As Stokes denoted in a paper on banking confidentiality history in England, the subject is "a very partially investigated branch of law." Some claim that the

\footnotetext{
${ }^{8}$ Hooper v. Barnett Bank of West Florida, 454 So. 2d 1253, 1257-1259 (1985).

${ }^{9}$ Brex v. Smith, 104 N.J. Eq. 386, 390 (1929).

${ }^{10}$ Leonard v. State of Indiana, 249 Ind. 361, 365 (1968).

${ }^{11}$ See In re The June 1979 Allegheny County Investigating Grand Jury, 415 A.2d 73, 76 (1980)

${ }^{12}$ See clarification in Peterson v. Idaho First National Bank, 367 P.2d. 284, 289-290 (1961).

${ }^{13} 367$ P.2d. 284, 288-290 (1961)

${ }^{14}$ Some references, however were occasionally made. See Mangan (1981) and Rogovin (1986) at 594-597.

${ }^{15}$ See, for instance, Latimer (1996).

${ }^{16}$ For instance, Bernfeld (1972) at 12-13. claimed that solicitor-client testimonial privilege as a prototype of professional confidence was the most long-standing of all. In a later work, Shuman (1985) at 667-677, found that the privilege of lawyers and clients as well as clergymen is older than the patient-physician privilege, which seems to have emerged only in the late 18 century. What is more obscure, the early English common law does not mention banking confidentiality at all, apart from the cases cited in Tournier v. National Provincial Bank of England, [1924] 1 K.B. 461.
} 
history of banking confidentiality may date back to the $16^{\text {th }}$ century. ${ }^{17}$ It could be contended that banking confidentiality may have been a matter of tradition, at least for such countries such as Switzerland, which have a very old and elaborate statutory legislation on the subject; some authors claim that data confidence was a bank tradition before being codified; ${ }^{18}$ at the same time, it is limited by various federal and Cantonian laws. ${ }^{19}$ Swiss case law seems to confirm the existence of such a practice, though it seems that nearly every time Swiss courts faced a banking secrecy breach, it was likely to be a clash between public body duties concerning bankruptcy, ${ }_{20}^{20}$ revenue, ${ }^{21}$ or a probate trial requiring some very specific bank account facts. ${ }^{22}$ At the same time, a tax evader holding a public position was unsuccessful in his attempt to forbid a newspaper from disclosing facts regarding his machinations. ${ }^{23} \mathrm{~A}$ breach of economic secrecy, both of ordinary employees (e.g. information regarding their wages and similar data), ${ }^{24}$ as well as enterprises, ${ }^{25}$ is criminalised in this country. Early on, Switzerland recognised the extension of a statute-originating personal right to privacy in case law, ${ }^{26}$ in contrast to Germany, for example, where privacy is a case law-originated right and has no other similar general statutory codification except the Constitution. ${ }^{27}$ In more recent case law in Switzerland, courts found that an action for unauthorised public disclosure of private facts may be subject to injunctive relief. ${ }^{28}$ However, the confidential communications concerning highly sensitive data, such as a criminal conviction, seem to be non-actionable in this country. ${ }^{29}$ At the same time, it may the complete opposite in civil suits. ${ }^{30}$

The notion of banking confidentiality in England was seemingly known around a century prior to Tournier, being recognised in various dicta and decisions, though less known than the case cited above. One of these cases, Foster v. Bank of London, featured the action of a merchant who sued the bank for disclosing his account details to one of his creditors, who then placed money in his account for the sum he was indebted; this financially ruined the merchant, and he won his case. ${ }^{31}$ In Dixon v. Holden, a merchant was repeatedly intimidated by the creditors of his former business partner to return loans he had never taken;

\footnotetext{
${ }^{17}$ See Kelly (1976) at 213-214; De Capitani (1988).

${ }^{18}$ Guex (2000) at 240.

${ }^{19}$ Dumant and Wassmer (1988).

${ }^{20}$ Banque de X. \& Cie. c. Etat de Fribourg, BGE 64 I 187, 193-194 (1938).

${ }^{21}$ Konkursverwaltung der Kredit- und Verwaltungsbank Zug AG, BGE 86 III 114, 115-118, 120 (1960).

${ }^{22}$ Caisse d'épargne de Bassetcourt c. Choffat, BGE 89 II 87, 93-94 (1963).

${ }^{23}$ Schärer g. N.N., BGE 73 IV 27, 31-34 (1947).

${ }^{24}$ Thurgau g. Dändlicker, BGE 65 I 47, 49-51 (1938).

${ }^{25}$ Schweizerische Bundesanwaltschaft g. A., BGE 98 IV 209, 210 (1972); see also comment on business secrecy crime punishment, Meier (1970) at 19-20.

${ }^{26}$ See De Vietinghoff c. de Niederhausen, BGE 44 II 319, 320-321 (1918). Concerning original Swiss statutes, see Muller (2010).

${ }^{27}$ See the discussion on the Swiss and German privacy protection in BGHZ 35, 363, at p. 367 (1961)

${ }^{28}$ Metzler g. Philanthropische Gesellschaft Union und Mitbeteiligte, BGE 97 II 97, 100-101; 106108 (1971).

${ }^{29}$ Sidler g. Litschgi, BGE 81 IV 281, 283-285 (1955).

${ }^{30}$ See Z. g. M und Kantonsgericht von Graubünden, 80 I 1, 2-3; 5 (1954)

${ }^{31}$ Foster v Bank of London, 3 F. \& F. 214, 215-217 (1862).
} 
in fact, these loans were taken by his brother, whose firm had gone bankrupt over a decade earlier. The creditors threatened to publish his "debt details" in the local press, and so he sued them for libel, and won. ${ }^{32}$ The report does not disclose the source for the account details that the creditors possessed: it might have been the bank, or possibly some registry. Nevertheless, the said institutions were not named as a party in this trial.

The history of banking confidentiality in the United States, initially based in the early-to-mid- $20^{\text {th }}$ century upon the Brex vs. Smith, ${ }^{33}$ Zimmerman and Peterson, found its beginning quite close to the English boundaries. In the late 1820 s, the New York Supreme Court found that an oral disclosure of a holder's conjectural incredibility is actionable, upon the theory of slander. ${ }^{34}$ In a 1820 s trial in Canada, a shareholder, Baldwin, had maintained twenty shares of capital stock and, aspiring to the position of bank director, desired to inspect bank records in order to gain information regarding the shares of stockholders. The Upper Court of Queen's Bench (per Sherwood, J.) held that a writ of mandamus could be given if Baldwin gave a proper cause of inspection; had he been the director, he would likely have succeeded in his endeavour, but Baldwin lost the case as he neither gave a valid reason for his request, nor was he on the board. ${ }^{35}$ In the 1908 trial of Montgomery v. Ryan, which was a precursor of Tournier, the bank assigned the depositor's overdraft and it's securities to a third party, after disclosing all his bank records to the assignee. The plaintiff put his claim upon a violation of a Canadian act regulating the activity of banks, but failed, as the Court found that the bank exercised its powers properly. ${ }^{36}$

This brings us to Tournier, a leading case on banking data privacy. The facts of the case were simple. Tournier, a poor man, received a $10 \mathrm{GBP}$ overdraft from the defendant and negotiated to pay weekly instalments totalling 1 GBP, which he ceased to pay after three payments. He then began temporary employment at a firm named Kenyon \& Ko., after which his cheque was obtained by a third party, later revealed to be a bookmaker. The bank manager called the directors of plaintiff's place of employment and told them the plaintiff had some debts and had been involved in betting. Subsequently, Tournier was deemed to be an unreliable person to work with, was fired and filed an action against the bank upon the theories of implied contract and slander, succeeding in both. The Court ascertained that the banker-customer relationship was one of confidentiality and announced a number of facts under which confidentiality may be assumed. ${ }^{37}$ US courts have repeatedly cited the Tournier case and have mainly followed the English decision. ${ }^{38}$

In Germany, banking secrecy also came under discussion quite early. Before the enactment of the 1947 Constitution, where the right to privacy was

\footnotetext{
${ }^{32}$ Dixon v Holden, L.R. 6 Eq. 485, 490-492 (1869).

${ }^{33}$ Brex v. Smith, 104 N.J. Eq. 386, 390-391 (1928).

${ }^{34}$ Sewall v. Catlin, 3 Wend. 291, 294 (1829); Ostrom v. Calkins, 5 Wend. 263, 264 (1830).

${ }^{35}$ In re The Bank of Upper Canada v. Robert Baldwin, Dra. 55, 58-59 (1829).

${ }^{36} 16$ O.L.R. 75 (1908).

${ }^{37}$ Tournier v National Provincial Bank of England [1924] 1 K.B. 461, 462-463; 467-468; $472-474$

[per Banks, J.]; 476-477; 480-481 [per Scrutton, J.]; 484-485 [per Atkin, J.].

${ }^{38}$ See Suburban Trust Co. v. Waller, 408 A.2d 758, 763-764 (1979).
} 
treated under a "personal right" provision (Persönlichkeitrecht), the general right to privacy had never been codified, ${ }^{39}$ though occasionally spotted in case law. ${ }^{40}$ Commentators could not come to a conclusion regarding its origins, other than that the German privacy tort claimed to have a case-law nature (somewhat similar to the US) by the Supreme Court. ${ }^{41}$ In 1927, the German Supreme Court, known then as the Reichsgericht faced a cunning suit: a merchant won a suit against a credit history reporting agency, filed for disclosing facts of his criminal past despite the fact that he was pardoned two decades earlier, on the grounds of a "breach of good morals," which probably would be tantamount to a US tort of mental anguish or outrage. ${ }^{42}$ In a 1950 s trial, a Berlin owner of a local bank found himself under severe debt, and reached an agreement with fellow banks to credit him in order to avert bankruptcy. In the meantime, a local paper published that he was about to be bankrupt. The plaintiff sued several defendant parties for a bank secrecy breach, but failed, as the Federal Supreme Court found that the publication didn't cause him to be ruined; at the time of the publication, he was, in fact, bankrupt or very close to bankruptcy. ${ }^{43}$

\section{Derogations}

The rationale of banking confidentiality is quite apparent and is based upon mutual trust, which is recognised both in Anglo-Saxon and Continental case law: the client has a duty to furnish his personal data, which may be of quite a sensitive nature, and at the same time the bank has a duty not to divulge this information, other than in a number of very limited situations. If bank confidentiality would not be an inherent feature of the interaction between bank and client, the public would have no confidence in the banks. ${ }^{44}$ The Swiss

\footnotetext{
${ }^{39}$ In most German privacy cases, the plaintiffs base their claims upon $\$ 823.1 \mathrm{CC}$ (protection of liberty, property, freedom and collateral rights, but the right to privacy had never been actually specified in the code provision), as well as $\$ 12$ BGB in some earlier cases (copyright protection), see e.g. Graf Zeppelin, RGZ 74, 308; case No. 688/09 (1910) at 310.

${ }^{40}$ The German privacy cases are not much newer than the US ones. See: Fraulein G. Sch. case, RG vom. 29 Nov. 1898, D. 4098/98 VIII 8145 [unauthorised commercial disposal of photo of a woman in a swimming pool, defamation]; Otto von Bismarck case, VI. 259/99; RGZ 45, 170, at p. 172-173 (1899) [unauthorised photo of von Bismarck corpse, trespass]; RGZ 51, 369; No. IV 50/02, at. p. 373; 380-et seq. (1902) [blacklisting of workmen, moral offence, held non-actionable on various grounds]; Nietzsche case, RGZ 69, 401; 638/07 (1908) [publication of private letters, copyright]; Graf Zeppelin, RGZ 74, 308; case No. 688/09, at. p. 310-311 (1910) [appropriation of Count Zeppelin's name and likeness to advertise tobacco products, copyright]; Dierig, RGZ 91, 350, 360 etc. (1917) [alleged violation of the reputation of a factory owned by the plaintiff's father by historical facts quoted in a scientific paper, found non-actionable as the facts were proven to have originated from archives]. For an early discussion of some German cases concerning photography, see Kohler (1903) at 28-44.

${ }^{41}$ See Scheyhing (1960) at 508-513.

${ }^{42}$ IV 489/26, RGZ 115, 416, at p. 417-419 (1927).

${ }^{43} \mathrm{BGH}, 20.12 .1955$ - I ZR 171/55, para. 4-14; 32-33 (1955).

${ }^{44}$ In fact, the duty of a customer to furnish correct personal information is not ephemeral, otherwise he may be charged for fraud, see Djowharzadeh v. City Nat'l Bank \& Trust Co. of Norman, 646 P. 2d 616, 619 (1982).
} 
Federal Tribunal, adjudicating a case where a bank employee was accused of stealing a magnetic tape with a computer program from the bank, said:

"To a large extent, relationships between banks and their customers depend on their confidence in the bank's discretion with respect to matters relating to client's private sphere of life. If there is no guarantee that such facts, once revealed or learned, will remain secret; then the client's confidence in the bank would disappear, and hence, one of the essential conditions for a viable banking business would collapse." 45

Thus, the exceptions are deemed to be few and justified upon appropriate case law. These exceptions were first discussed in the case of Tournier; during the discussions of this case, the court determined the four instances in which it would be legal to divulge bank clients' personal data: a) when the revelation is in compliance with the law; b) when there is overriding public interest (e.g. prevention of crime); c) when the disclosure is in the interests of the bank (primarily in trials when the bank is named as a party); d) when the client consents to it. ${ }^{46}$ These principles were firmly followed in England, even if not cited directly. In Williams $v$ Summersfield, the accused sued a constable for ordering the inspection of their bank accounts in order to search for further evidence; this was done in compliance with the 1879 Evidence Act provision. The Court found that the order was made by a party of the proceedings and that further evidence, including that obtained by inspection of the books, was justifiably required. ${ }^{47}$

In a similar case in 1980, a police officer applied for an order to inspect a suspect's bank account "book", but the information he needed as evidence was stored on microfilm, rather than on paper. The High Court backed the lower one's decision, confirming that the police officer was a party of duly commenced proceedings and without a court order to disclose the records, it would be impossible to specify the benefactors of cheques paid from the accused's account and thus detect his fraudulent behaviour. The spirit of the aforesaid Evidence Act provision was successfully adapted to modern-day techniques: "A book is a word which is used in many contexts." 48 The prevention of crime, in particular financial crime, is often a reasonable "excuse" for derogating bank confidentiality. For instance, in the early 90s, the Italian Constitutional Court ruled that the provisions of the 1972 Presidential Decree, concerning lifting bank secrecy in respect to tax evasion and financial crime investigation upon the request of prosecution and law enforcement bodies, are constitutional. ${ }^{49}$

Despite the fact that a number of US state courts appraised and applied the principles of Tournier, there were contrary views on the issue of derogation. Indeed, in Suburban Trust Co. $v$ Waller, the respondent applied for an income

\footnotetext{
${ }^{45}$ C c. Ministère public du canton de Vaud, BGE 111 IV 74, 80 (1985) Translated from French).

${ }^{46}[1924] 1$ K.B. 461, 473.

${ }^{47}$ [1974] 2 Q.B. 512, 516-519.

${ }^{48}$ Barker $v$ Wilson [1980] Q.B. 884, 886-887.

${ }^{49}$ La Corte Constituzionale, Sent.No. 51 del. 1992.
} 
tax refund check to be cashed, but was told his balance was not enough to cover it, so he took a friend who required a similar check cashed and went to the Treasury Department, where they received the money with bills having sequential numbers and deposited them to the bank. An inexperienced employee believed the bills might be suspicious and informed a security officer, who made a series of inquiries and was informed by a police chief that there had been a recent robbery, describing the main suspects; the security officer believed that Waller and his friend were these suspects and subsequently revealed all of Waller's bank records to the police chief. The victim identified Waller as the perpetrator from a photograph, but after Waller was captured and put on trial, the victim retracted his identification and Waller was discharged. After that, he sued the bank for privacy invasion and breach of contract. While considering the issue of bank-depositor relationship, the Court took Tournier into account and upheld that secrecy is an implied contractual duty of non-disclosure, but rejected the wide range of derogations, stating:

"We do [reject the derogations set in Tournier decision] because we believe that those two authorities confer upon the bank entirely too much discretion. Were we to follow Tournier, or 10 Am. Jur. 2d. Banks para. 332 [the annotation], we would permit a bank to decide what is or is not the best interest of the bank to disclose."

The Court also emphasised that Maryland's legislature enacted provisions concerning banking secrecy which were far more strict than the "proposed" English ones, namely a) upon the customer's consent; b) upon a court order, subpoena or other warrant. Waller won his case upon the theory of implied contract. $^{50}$

The derogations of banking confidentiality in other situations could are varied. For instance, in Switzerland the law applies different boundaries of secrecy and the case law ascertains that bank confidentiality may be breached in situations of cooperation between Switzerland and other countries such as Germany $^{51}$, England ${ }^{52}$, or the United States, ${ }^{53}$ in order to provide legal assistance in criminal matters (e.g. tax evasion or financial frauds). While the "limits of secrecy" in civil and criminal procedure in Switzerland are beyond the scope of this paper, it is quite apparent that a testimonial privilege may be overrun by a court order when an offense is suspected. ${ }^{54}$ Swiss case law holds that bank secrecy cannot be used as a defence to seal assets or other bank documents from creditors. $^{55}$

\footnotetext{
${ }^{50} 408$ A.2d 758, $762-765$ (1979).

${ }^{51}$ X. g. Eidgenössische Bankenkommission, BGE 125 II 83, 84-85 (1998).

${ }^{52}$ E. g. X Bank Corp., BGE 120 II 118, 119; 121-123 (1994).

${ }^{53} X$. und Y-Bank g. Eidgenössische Steuerverwaltung, $101 \mathrm{Ib}$ 160, 163 (1975) [note the 1973 Treaty].

${ }^{54}$ X. g. Staatsanwaltschaft und Kantonsgerichtsausschuss von Graubünden, BGE 91 I 200, 204-207 (1965).

${ }^{55}$ La Cause Dubois, BGE 85 III 118, 120 (1959).
} 
In Germany, bank secrecy must be unveiled in the course of preliminary investigations against a bank customer or employee; the bank is under obligation to produce all necessary evidence concerning the investigation. It is emphasised that not all documents are to be disclosed, but only ones relevant to the investigation. ${ }^{56}$ In several continental jurisdictions, such as Germany, ${ }^{57}$ Switzerland, ${ }^{58}$ Austria $^{59}$ and Liechtenstein, ${ }^{60}$ the disclosure of a deceased testator's account records to heirs is allowed within a probate proceeding; it does not constitute a bank secrecy violation and all heirs are entitled to view the necessary records; other heirs cannot be deprived of inspecting the testator's records. In Austria, a minor may be obliged to divulge his bank account details to a foster parent under certain circumstances, or disclose it voluntarily, but the bank or a credit reporting agency is not compelled to reveal the information to a foster parent. ${ }^{61}$

In a 1970s US trial, several policemen, who were suspended for refusing to provide information regarding their financial assets, brought an action against the commissioner. The Court deemed that it was not a public disclosure and that it is in society's best interest to maintain honest public servants, finding that the questionnaire regarding the policemen's financial assets did not violate their right to privacy. ${ }^{62}$ In the 1970 s and 80s, United States courts repeatedly affirmed the constitutionality of statutes requiring holders of public office to disclose their financial records, and frequently also the records of their spouses. ${ }^{63}$ Sometimes, the legislature's demands were found to be outrageous: in Denoncourt, several school directors filed a class action against the Pennsylvania Ethics Commission. Based upon the abovementioned 1978 act, the directors, apart from having an obligation to disclose a variety of personal financial records, were required to provide the records concerning immediate relatives; moreover, one of the act's sections criminalised their failure to comply with the request, imposing criminal liability for not fulfilling it, not for unwillingness or sabotage. The plaintiffs alleged that both prosecution for nonfulfillment and the request to disclose family members' financial records were unconstitutional. The Court found that since criminal liability may arise from actions with which the public official may not comply, this violates due process. The Court also determined that privacy rights are to be carefully balanced against state interests, and though it may be reasonable to demand the disclosure of an official's financial affairs, this is not the case for family members, whose privacy interests may be impaired. ${ }^{64}$

\footnotetext{
${ }^{56}$ See LG Hamburg, Beschluß von 10.01.1978, (86a) Qs 68/77; NJW 1978, 958, at p. 958-959.

${ }^{57}$ BGH 107, 104; XI ZR 91/88, para. 12-15 (1989).

${ }^{58}$ Caisse d'épargne de Bassetcourt c. Choffat, BGE 89 II 87, 93 (1963).

${ }^{59} 8 \mathrm{Ob} 167 / 67$, Decision of June 27, 1967; 4 Ob 506/74; HG Vienna 3R 178/73, Decision of 5 March 1974; OGH 4 Ob 522/84; Decision of 27 February 1985.

${ }^{60}$ F.L. OGH 16.08.1993; 4C 170/32-23, 1 Bosch 58, at p. 62-63; 65-66.

${ }^{61} 8 \mathrm{Ob} 71 / 70$; LGZ Vienna 44R 542/69, Decision of April 7, 1970.

${ }^{62}$ O'Brien v. DiGrazia, 544 F.2d 543, 546 (1976).

${ }^{63}$ Kenny v. Byrne, 365 A.2d 211, 216-218 (1976).

${ }^{64}$ Denoncourt v. Commonwealth State Ethics Commission, 479 A.2d 945, 948-950 (1983).
} 
In several cases, the United States courts held that banks have an obligation to disclose the financial condition of the second party transaction, in cases where there is clear evidence that the said party may be involved in swindling, is in debt or bankrupt. ${ }^{65} \mathrm{~A}$ subpoena could also be issued to produce banking records. ${ }^{66}$ For instance, in the Addonizzio trial, a town's mayor accused of various financial machinations appealed against a subpoena compelling him to surrender all of his bank records and defended himself on basis of the $4^{\text {th }}$ Amendment. Interestingly, he succeeded not on this basis, but based on the fact that the bank records were the property of the bank, not his own; the Court emphasised that the plaintiff would not have been able to successfully challenge this subpoena had it been addressed to the bank, rather than him personally. ${ }^{67}$ A subpoena requiring the bank to produce bank records must be issued in the course of legal proceedings, otherwise it may be deemed invalid. ${ }^{68}$ Some American courts held that the customer's debts to the bank cannot possess the label of "banking secret", as the bank acts as a lender and does not possess a duty to keep the debt records as secret. In such cases, the information may be divulged only to authorised individuals, and thus the disclosure of debt facts is non-actionable upon the theory of implied contract, but may be actionable upon privacy invasion if it is disclosed in public. ${ }^{69}$ A disclosure of banking records, especially records that feature loan facts to a law enforcement officer, also does not constitute a breach of an implied contract. ${ }^{70}$

\section{Tort and Contract Law Principles in Civil Actions Involving the Disclosure of Bank Records}

In various trials occurring in commonwealth states concerning the disclosure of bank records of depositors, the courts applied tort and contract law principles, and occasionally, issues of property rights. For instance, in one of the earliest cases on the subjects in the United States, Brex v. Smith, a public prosecutor demanded that the bank accounts of all policemen Newark Police Department be disclosed without any proceedings, stating that the court of equity cannot preclude him of doing this. The Court confirmed his statement, adding that it was correct except in situations where public authorities are acting without authority and property rights are involved; there was no criminal proceeding, and concerning the property rights, the court said: "There is an implied obligation, as I [Church, V.C.] see it, on the bank, to keep these [records] from scrutiny until compelled by a court of competent jurisdiction to do otherwise. The information contained in the records is certainly a property right.". Thus, the court enjoined him, inter alia, upon the property right of the bank in the

\footnotetext{
${ }^{65}$ See e.g. Richfield Bank \& Trust Co. v. Sjogren, 244 N.W. 2d 648, 651 (1976).

${ }^{66} \mathrm{See}$ fn. 3 supra; for some more contemporary cases. See, e.g. Twiss v. State Dept. of Treasury, 124 N.J. 461, 474-475 (1991); Hirl ex. rel. Hirl v. Bank of America, 952 A.2d 479, 483-484 (2008).

${ }^{67}$ In Re Addonizio, 53 N.J. 107, 131-132 (1968).

${ }^{68}$ Commonwealth v. DeJohn, 486 Pa. 32, 40-41; 47-49 (1979).

${ }^{69}$ Graney Development Corp. v. Taksen, 92 Misc. 2d. 764, 767-769 (1978).

${ }^{70}$ Indiana National Bank v. Chapman, 482 N.E.2d. 474, 480-482 (1985).
} 
customer records. ${ }^{71}$ In a federal trial of Zimmerman $v$. Wilson, a husband and a wife filed an action to restrain revenue officers from examining the bank accounts of plaintiffs, and the Court found for the plaintiffs, based upon the constitutional provisions of unreasonable search and seizure. ${ }^{72}$ While the claim for an invasion of privacy may be logical, it is not very successful at trials in the United States: the matter is that courts usually recognise the scope of a privacy invasion upon a fourfold classification. The disclosure of banking records does not fall under this classification, namely public disclosure of private facts: it cannot be claimed that disclosure to a creditor, or, more frequently, an employer, is public. The case of Peterson v. Idaho National Bank illustrates this principle precisely. The plaintiff was an employee at Family Finance Corp. in Lewiston, Idaho. One day in autumn 1959, the manager of the company in Denver, Colorado, contacted the bank and suggested one of the employees, Peterson, may be discreditable and harmful to the enterprise. The bank manager sent the manager a confidential letter confirming Peterson had severe financial problems and then revealed additional information regarding his accounts, unbeknownst to the plaintiff. The Idaho Supreme Court said the state had neither statutory regulation of the subject, nor a common law right to privacy recognised. The plaintiff did not contend that the disclosure was public, although he filed the claim upon a violation of privacy. The Court cited a number of Tournier-like trials, ${ }^{73}$ where no liability was imposed upon the defendant under a privacy claim, in situations where the defendant privately disclosed one's debts or financial conditions to an employer. The Court held that the action may be maintained upon a breach of implied contract, citing Tournier, as well as earlier US cases on the subject, such as Zimmerman. ${ }^{74}$ In the later trial of Chapman, the plaintiff filed a multi-claim action for disclosing bank records concerning a loan to a police sergeant, including one count of privacy invasion; the Court examined various types of "contemporary" privacy violation, such as eavesdropping, but found that bank records disclosure was non-actionable as it lacked the component of publicity. ${ }^{75}$

A breach of implied contract seems to be the most suitable basis from all of the theories upon which recovery may be granted. The gist of this theory is that banks possess a duty not disclose the records of their customers under ordinary circumstances; and so, when the client commences relationships with the bank, there exists an implied contractual obligation of non-disclosure of the records that are related to depositors. Such an approach was upheld in various well-known American trials, such as Milohnich ${ }^{76}$ Sjogren, $^{77}$ Waller $^{78}$ and others. The implied contractual duty was also recognised in earlier dicta. ${ }^{79}$ This duty is

\footnotetext{
${ }^{71}$ Brex v. Smith, 146 A. 34; 104 N.J. Eq. 386, 390-392 (1928).

${ }^{72}$ Zimmerman v. Wilson, 81 F.2d 847, 849 (1937).

${ }^{73}$ See e.g. Levis v. Physicians etc. Bureau, 27 Wash. 2d 267, 271-273 (1947).

${ }^{74} 367$ P.2d 284, 288-290 (1961).

${ }^{75}$ Indiana National Bank v. Chapman, 482 N.E.2d. 474, 477-479 (1985).

${ }^{76} 224$ So. 2d 759, 761 (1969).

${ }^{77} 309$ Minn. 362; 244 N.W. 2d 648, 651 (1976).

${ }^{78} 44$ Md. 335; 408 A. 2d. 758, 762-765 (1979).

${ }^{79}$ United States of America v. First National Bank of Mobile, 67 F. Supp. 616, 624 (1947).
} 
not applicable in cases when the plaintiff is not just a customer, but also a debtor: in the 1970s trial of Taksen, the plaintiff's debt details were revealed to another bank, and he filed a multi-claim action against the bank; the Court found the count for an implied contract breach non-actionable, as a debtor cannot expect to have his debts kept in confidence, and these may be divulged in a limited circle of instances. ${ }^{80}$

Sometimes, a theory of breach of confidence is applied. The gist of the tort is a disclosure of confidential information acquired within the relationship of the parties, regardless of its content; the same may be applied to bank secrecy. In the case of Djowharzadeh, the plaintiff decided to take a loan from a bank in order to purchase a duplex house. This information was disclosed to both wives of the bank's managers by a loan officer, and both women decided to overrun the plaintiff and buy the premises for themselves. Apparently the plaintiff knew nothing about these developments, though he was refused the loan. During the trial, the bank employees did not deny they had revealed the records and contended they had no legal duty to keep the information secret; but the Court ruled that there was a common law-originating duty of confidence, stating that it originated from reciprocal duties - to furnish the personal data accurately from the customer, and to maintain it properly from the bank. Thus, the Court held the claim to be actionable. ${ }^{81}$

On some occasions, actions for fraud and deceit may be filed for nondisclosure of a transaction party, which may be bankrupt or have substantial financial difficulties. In the case of Sjogren, respondents negotiated to purchase five dozen purification units from an enterprise entitled National Pollution Eliminators, Inc.; they decided to take a 44,000 dollar loan from Richfield Bank \& Trust Co., with a 90-day promissory note and some real estate, including the purification machinery, as securities. Soon the NPE was found to be insolvent and unable to supply the machinery, though the bank officer did not disclose this fact prior to the loan deal. The Court admitted that despite the general duty not to disclose the depositor's account details, it was the duty of the bank officer to report his knowledge of fraudulent activities or "irretrievable insolvency". the Court added that not every insolvency instance is fraud, as the machinery could have been purchased on credit, but this was not the case, as there was no reasonable expectation to fulfil the contract obligations. The loan officer knew that NPE actually was deeply insolvent, and the court affirmed the lower court's order for the plaintiff. ${ }^{82}$

In a similar case of $\mathrm{Nie}$, an employee of an agricultural enterprise dealing with pig feeding received a substantial inheritance and was advised to invest in the said company and another one, both owned by his employer, Dunnegan. $\mathrm{He}$ accepted this advice and took his boss and family to the bank to check the financial condition of both businesses. The bank did not reveal that both enterprises had large debts and overdrafts, though they were up-to-date on their loan payment. After a certain time period the plaintiff learned about the enterprises' solvency

\footnotetext{
${ }^{80}$ Graney Dev. Corp. v. Taksen, 92 Misc. 2d. 764, 767-769 (1978).

${ }^{81}$ Djowharzadeh v. City National Bank \& Trust Co., 646 P2d. 616, 619-620 (1982).

${ }^{82}$ Richfield Bank \& Trust Co. v. Sjogren, 244 N.W. 2d 648; 309 Minn. 362, 367-369 (1976).
} 
problems, and even took loans and went into debt in order to try and save the companies. Finally, he sued the bank for fraud for not revealing all the relevant bank records. The Court found that the loan officers who advised the plaintiff were in the hog business themselves and were familiar not only with Dunnegan and his enterprises, but with their actual financial condition. The court found the nondisclosure to be actionable and remanded the case, as at the time the loans were current and, as far as the bank knew, the companies were making money and represented a good investment. ${ }^{83}$ Not all US courts support this position. In Sparks, for example, the plaintiff decided to take up a loan to construct a building, expected to be leased to one Williams. The bank agent knew Williams had been insolvent, but concealed this, presenting him as wealthy and credible. A year later Williams' assets were seized and thus he was unable to pay the rent. Sparks sued the bank for over a thousand dollars in damages, but the Court found that the bank had no duty of obligation to disclose Williams' state of financial affairs, as it was required to maintain secrecy. ${ }^{84}$

\section{International Law Concerns}

The issue of banking secrecy has never received a concordant legacy in international law. The primary legacy could be observed in case law originating from Switzerland's bilateral covenants. For instance, in 1951 Switzerland bargained a treaty with the United States to avoid double taxation, and they agreed, inter alia, to exchange data under request regarding economic crime investigation; in order to obtain information, the American authority had to contact the Swiss authority and a court order would enable dataflow to be transported to the United States. ${ }^{85}$ In late 1968, the United States applied to inspect records concerning several Zurich bank employees, their comrade in Washington, and an another US citizen (not named in the case report), who repeatedly acted fraudulently, forging document for over three million dollars and depositing embezzled funds in a Swiss Bank. The Zurich district attorney's office granted American authorities access to the criminal records upon their request, but the plaintiffs appealed. The Swiss Federal tribunal found the order to be legitimate and recognised the United States as "an injured party" as well as ascertaining that the American authority should make a formal declaration that the data revealed must not be afterwards disposed for fiscal purposes. ${ }^{86}$ In November 1972, the US Internal Revenue Service (hereinafter - IRS) asked the Federal Tax Administration of Switzerland not only for the bank records, but to produce witness testimony concerning tax fraud cases, as well. Two Swiss banks were compelled to divulge the said documents; their prior administrative complaints were rejected. On appeal, the Swiss Federal Tribunal held that the

\footnotetext{
${ }^{83}$ Nie v. Galena State Bank \& Trust Co., 387 N.W. 2d 373, 375-376 (1986).

${ }^{84}$ Sparks v. Union Trust Co. of Shelby, 256 N.C. 478, 480-483 (1962).

${ }^{85}$ Dunant and Wassmer (1988) at 554-556.

${ }^{86}$ N. g. Vereinigte Staaten von Amerika, Bezirksanwaltschaft Zürich und Staatsanwaltschaft des Kantons Zürich, BGE 95 I 439, 440-442; 447-448 (1969).
} 
bilateral agreement was bound to written reports and didn't presuppose any actual judicial assistance; nor was the 1973 treaty any help: despite the fact that Switzerland and the United States agreed to exchange data concerning fiscal crimes, including testimony, this was mainly regarding high-level criminals, and as the said treaty was not in force by 1975 , the appeal was allowed. ${ }^{87}$

In fact, Switzerland has negotiated around a dozen such treaties with other countries. ${ }^{88}$ However, the existing case law shows that banking data were not once transmitted upon bilateral agreements to other countries. ${ }^{89}$ Switzerland's international agreements were also the cause behind various data privacyrelated trials. For instance, one bank employee from Zurich opened a deposit account for an Englishman, who lodged over 8 Million CHF by portions in 1987; upon a request for assistance, the bank launched an investigation and found the money deposited was, in fact, laundered money originating in a gold heist. The employee was immediately fired and lodged three actions against the bank, namely 1) to return him to his place of employment; 2) to recover damages for his discharge; 3 ) to allow him access to his personal file and two reports from an English detective agency so as to gain necessary evidence. All trials were lost and he appealed to the federal court. The Tribunal dismissed his appeal, as 1) sufficient testimony was introduced that the information he sought was not in his personal file; 2) the right to access is granted to ascertain whether the records contain a potential violation of his "personal rights", e.g. the records are false or not related to his employment, and so these may be used as evidence for trial. However, he didn't apply for a court order to produce the documents in order to fulfil this specific purpose; in fact, the appellate court also dismissed his access-to-record claim on the basis that he hadn't stated a justifiable cause for obtaining the records after the termination of his contract. This was not contested before the Tribunal. ${ }^{90}$ It should be noted that regardless of being a "code law" legal system, Swiss law has a large case law legacy regarding access to personal files involving a wide variety of situations, such as disclosure of one's deportation, ${ }^{91}$ public office employment history and related subjects, ${ }^{92}$ police files ${ }^{93}$ and much more.

While issues of data privacy within banking secrecy have been discussed often within the context of international law, they are seldom mentioned in the practice of international human rights courts. On this matter, the most comprehensible and systemised practice is elaborated by the European Court of Human Rights under Art. 8 of the Convention, upon which all the relevant case law is based. ${ }^{94}$ The European Court has been required to address issues of data

\footnotetext{
${ }^{87}$ X. und Y-Bank g. Eidgenössische Steuerverwaltung, 101 Ib 160, 163-165 (1975).

${ }^{88}$ Dunant and Wassmer (1988) at 552.

${ }^{89}$ X. g. Eidgenössische Bankenkommission, BGE 125 II 83, 84-85 (1998).

${ }^{90}$ E. g. X Bank Corp., BGE 120 II 118, 119; 121-123 (1994).

${ }^{91} X$. g. den Regierungsrat des Kantons Y, BGE 95 I 103, 106-111 (1969).

${ }^{92}$ Demont et al. c. Conseil d'Etat du canton de Genève, BGE 100 Ia 97, 102-103; 106 (1974).

${ }^{93}$ M. g. Regierungsrat des Kantons Zürich, BGE 113 Ia 1, 8-9 (1987).

${ }^{94}$ The first privacy trial of the European Court commenced in 1971 (Klass et al. v. The Republic of Germany, 2 EHRR 214), and decided in 1978. However, before 1978 there were instances where Art. 8(1) of the ECHR was disposed as a provision on the basis of which courts granted injunctive
} 
privacy since the 1970s, though such cases are not frequent: for instance, some entries featured personal records retention, ${ }^{95}$ intelligence records discovery, ${ }^{96}$ and several cases discussed access to medical records. ${ }^{97}$ However, banking secrecy violation is quite a novel issue within international law. To fall within the scope of "private and family life", the Court has to affirm cognisance over a case under a claim for a privacy violation, such as the matter of medical records in the trial of Gaskin, ${ }^{98}$ or with storing and maintaining criminal records by a national intelligence body, as in Rotaru, ${ }^{99}$ or by the penitentiary authorities, as in the relatively recent trial of Khehili. ${ }^{100}$

The 2010s featured two trials on banking confidentiality. In B.F.B. VillaNova v. Portugal, the plaintiff was a possessor of a local law firm suspected of tax evasion, which allegedly occurred around 2006. The revenue office requested that the plaintiff produce her banking records. She refused, relying on bank secrecy. The revenue office then passed the matter to the prosecutor's office, who applied for an order at a local appellate court, which ruled that the secrecy should be lifted. The plaintiff was not allowed to appeal and thus lodged a lawsuit to the ECtHR. The Court recognised jurisdiction over a case on bank secrecy breach under Art. 8 of the Convention, and found that despite the fact that the ruling had a legitimate basis and was in compliance with Portuguese statutory and case law, the plaintiff wasn't notified regarding the trial and was thus not present at the trial, was not allowed to defend herself, and could not therefore appeal to the Supreme Court in order to reverse the appellate court judgment (which was, in fact, contrary to Portuguese case law); As a result, the Court found for the plaintiff. ${ }^{101}$ Another trial, G.S.B. $v$ Switzerland, arose from US-Swiss cooperation in the field of financial frauds. In 2009, the Internal Revenue Service

relief or damages. E.g. in Italy, in Celentano, Petacci e al. c. Palacci, Sent. 20 Apr. 1963, n. 990; 86 Il. Foro 877, 880; the relatives of Clarice Petacci, a lover of Benito Mussolini, sued an establishment for depicting details of her personality and life, being portrayed as impious in the 1930-40s in a book, and the Italian Supreme Court of Cassation (Corte Suprema Corte di Cassazione), acknowledging that despite the fact that Italian case law and doctrine did not recognise a common law right of privacy, the right to privacy must be recognised on basis of Art. 8(1) of the Convention (though not solely on this basis). Furthermore, this sort of privacy was "relational", since C. Petacci hadn't survived to the date of trial, as she was executed with the Italian dictator in 1945. A similar conclusion can be found in a subsequent Italian case before the same court, Rossi e al. c. Soraya Esfandiari, Sent. 27 Mar. 1975, n. 2129; 99 Il. Foro 2896, 2905. In a pioneering case, Tirreno Asso Film c. Caruso, Sent. 22 Dec. 1956 n. 4487, 80 Il. Foro 4, at p. 7-10, an Italian singer's life story was depicted in a film. The artist sued but failed as the Court held that there is no general right to privacy in Italy, apart from the protection of one's name and/or image, but not a life story. Swiss courts also cited Art. 8(1) of the Convention as a provision protecting data privacy: M. $g$. Regierungsrat des Kantons Zürich, BGE 113 Ia 1, 7 (1987), but not as a sole source of law, and the European Court already had case law on the subject by the mid-80s.

${ }^{95}$ Leander v. Sweden [1987] 9 EHRR 433. Compare, e.g. with Laird v. Tatum, 408 U.S. 1 (1972).

${ }^{96}$ Szulc v. Poland, [2013] 57 EHRR 5, 163-167 (see facts on pages cited).

${ }^{97}$ See for instance, Odievre v. France, [2003] F.C.R. 621.

${ }^{98}$ Gaskin v. United Kingdom, [1989] 12 EHRR 36.

${ }^{99}$ See Rotaru v. Romania, [2000] ECHR 92, para. 43.

${ }^{100}$ See Khehili v. Switzerland, [2011] ECHR 195, para. 15 et seq. (reported in French as Affaire Khelili c. Suisse).

${ }^{101}$ B.F.B. Villa-Nova v. Portugal [2015] ECHR 1049. 
of the United States suspected that a Swiss bank, UBS, assisted US taxpayers in tax evasion. The US and Swiss authorities agreed to cooperate and thus lodged a conjoint assistance request to the Federal Tax Administration to make an order to compel UBS bank to disclose over four thousand accounts, but the bank appealed to the Federal Administrative Court and the order was quashed; The US and Swiss authorities then negotiated another assistance protocol, which was later found to be valid by the same court. The plaintiff was one of the unfortunate people whose bank records were disclosed and he lodged a lawsuit to the Federal Administrative Court; after losing the trial, ${ }^{102}$ the plaintiff appealed to the Federal Tribunal, with no success. To wit, before the trial at Strasbourg, the plaintiff hadn't been accused of a single financial offence. Though the Court affirmed cognisance over matters concerning bank secrecy to be related to Art. 8, it found that such privacy interference was justified for the state's well-being and to eliminate the risk of jeopardizing the bank from being bound to survive, thus finding there was no violation of his right to privacy. ${ }^{103}$

\section{Conclusions}

Data privacy in relation to banking confidentiality is one of the most obscure types of personal information confidentiality, owing to its traditionalistic character regarding various professional bilateral legal relationships. The duty posed on the banks gives a right of action for a breach of implied contract, or confidence, or occasionally gives redress upon either regarding other tort doctrines, or civil code, or other statutory remedies. The history of banking confidentiality has been scantly researched and there is no uniform body of knowledge concerning its traditional, case law or statutory origins, which has seemingly developed over the last two centuries. Bank secrecy has various derogations, which are mostly similar in Anglo-Saxon and Continental law; despite this, there certainly are a number of unique characteristics which are relevant only to certain jurisdictions. The issues of data privacy within bank secrecy has received certain reflection in international law, partially deriving from human rights courts, and, to some extent, in national court trials concerning bilateral covenants intended to avoid double taxation, such as the agreements concluded between Switzerland and other state-parties. The prospective trials in international human rights courts raise a multitude of issues concerning derogations of secrecy in various instances, with a wide variety of trials to be examined by judges. Thus, comparative research on bank secrecy in the context of recent developments of right to privacy in both Commonwealth states and in Continental Europe is a quite lacking, and extremely needed.

\section{References}

Bernfeld, W.K. (1972). 'Medical Secrecy' in Cambrian L. Rev. 3:11-26.

\footnotetext{
${ }^{102} X$. und Y. g. Eidgenössische Steuerverwaltung, BGE 137 II 128, 133-135 (2010).

${ }^{103}$ GSB v. Switzerland, [2015] ECHR 1122, para. 75-98
} 
De Capitani, W. (1988). 'Banking Secrecy Today' in U. Penn. Journ. Int. B. 10:57.

Dumant, O. and M. Wassmer (1988). 'Swiss Bank Secrecy: Its Limits under Swiss and International Laws' in Case W. Res. J. Int'l L. 20(2):541-575.

Guex, S. (2000). 'The Origins of the Swiss Banking Secrecy Law and Its Repercussions for Swiss Federal Policy' in Business History Review 74:237-266.

Kelly, J.T. (1976). 'United States Foreign Policy: Efforts to Penetrate Bank Secrecy in Switzerland from 1940 to 1975 ' in Cal. W. Int. Law. J. 6:211.

Kohler, J. (1903). Das Eigenbild im Recht, Berlin: J. Guttentag, Verlagsbuchhandlung gmbh.

Latimer, P. (1966). 'Bank Secrecy and Confidentiality Law in Practice in Australia and Their Impact of the Control of Economic Crime' in Dickinson Journal of International Law 14:551-555.

Mangan, J.J.Jr. (1981). 'Reasonable Expectations of Privacy in Bank Records: A Reappraisal of United States v. Miller and Bank Depositor Privacy Rights' in $J$. Crim. L. \& Criminology 72:243-292.

Meier, W. (1970). 'Banking Secrecy in Swiss and International Taxation' in The International Lawyer 7:16-45.

Muller, T. (2010). 'Das Geheimnis und das Bankgkundeheimnis' in Jusletter 3 Mai 2010, 8-9.

Reese, S. (1962). 'Confidential Communications to the Clergy/Privileges in the Law of Evidence' in Ohio St. L. J. 24: 55-88.

Rogovin, M. (1986). 'Privacy of Financial Records' in Ann. Surv. Am. L. 587, 594597 (1986). 1986 Ann. Surv. Am. L. 587.

Scheyhing, Robert (1960). Zur Geschichte des Persönlichkeitsrechts im 19. Jahrhundert, 158 Bd. H 5/6 (1959-1960) 503, 508-513.

Shuman, D.W. (1985). 'The Origins of the Physician-Patient Privilege and Professional Secret', in Southwestern L.J. 39:661-687.

Sippel, J.A. (1994). 'Priest-Penitent Privilege Statutes: Dual Protection in the Confessional' in Cath. U. L. Rev. 43:1127-1163.

Whittaker, L. (2000). 'The Priest-Penitent Privilege: Its Constitutionality and Doctrine' in Regent U. L. Rev. 13:145-168.

\section{Cases}

\section{European Court of Human Rights}

F.B. Villa-Nova v Portugal [2015] ECHR 1049.

Gaskin v United Kingdom [1989] 12 EHRR 36.

GSB v Switzerland [2015] ECHR 1122.

Khehili v Switzerland [2011] ECHR 195.

Klass et al. $v$ The Republic of Germany [1978]2 EHRR 214.

Leander $v$ Sweden [1987] 9 EHRR 433.

Odievre v France, [2003] F.C.R. 621.

Rotaru v Romania, [2000] ECHR 92.

Szulc v Poland [2013] 57 EHRR 5, 163-167.

\section{United Kingdom}

Barkerv Wilson [1980] Q.B. 884. 
Dixon v Holden (1869) L.R. 6 Eq. 485.

Foster v Bank of London (1862) 3 F. \& F. 214.

Tournier v National Provincial Bank of England [1924] 1 K.B. 461.

Williams $v$ Summersfield [1974] 2 Q.B. 512.

\section{United States}

Brex v. Smith, 104 N.J. Eq. 386 (1929).

Commonwealth v. DeJohn, 486 Pa. 32 (1979).

County of Nevada v. MacMillen, 11 Cal. 3d 662.(1974).

Denoncourt v. Commonwealth State Ethics Commission, 470 A.2d 945 (1983).

Djowharzadeh v. City National Bank \& Trust Co., 646 P2d. 616 (1982).

Graney Development Corp. v. Taksen, 92 Misc. 2d 764 (1978).

Hirl ex. rel. Hirl v. Bank of America, 952 A.2d 479 (2008).

Hooper v. Barnett Bank of West Florida, 454 So. 2d 1253 (1985).

Illinois State Employee Assn. v. Walker, 57 Ill. 2d 512 (1974).

In Re Addonizio, 53 N.J. 107, 248 A.2d 531 (1968)..

In re The June 1979 Allegheny County Investigating Grand Jury, 415 A.2d 73 (1980).

Indiana National Bank v. Chapman, 482 N.E. 474 (1985).

Keenan v. Gigante, 390 N.E. 2d. 1151 (1979).

Kenny v. Byrne, 365 A.2d 211 (1976).

Laird v. Tatum, 408 U.S. 1 (1972).

Leonard v. State of Indiana, 249 Ind. 361 (1968).

Levis v. Physicians etc. Bureau, 27 Wash.2d 267 (1947).

Milohnich v. First National Bank of Miami Springs, 224 So. 2d 759 (1969).

Nie v. Galena State Bank \& Trust Co., 387 N.W. 2d 373 (1986).

O'Brien v. DiGrazia, 544 F.2d 543 (1976).

Ostrom v. Calkins, 5 Wend. 263 (1830).

Peterson v. Idaho First National Bank, 367 P.2d. 284 (1961) .

Plante v. Gonzalez, 575 F2d. 1119 (1978).

Richfield Bank \& Trust Co. v. Sjorgen, 309 Minn. 362 (1976).

Sewall v. Catlin, 3 Wend. 291 (1829).

Sparks v. Union Trust Company of Shelby, 124 S.E. 2d 365 (1962).

Suburban Trust Co. v. Waller, 44 Md. App. 335 (1979).

Twiss v. State Dept. of Treasury, 124 N.J. 461 (1991).

United States of America v. First National Bank of Mobile, 67 F. Supp. 616 (1947).

Zimmerman v. Wilson, 81 F.2d 847 (1937).

\section{Canada}

In re the Bank of Upper Canada v. Robert Baldwin, Dra. 55 (1829).

Montgomery v. Ryan 16 O.L.R. 75 (1908).

Austria

HG Vienna 3R 178/73, Decision of 5 March 1974.

OGH 4 Ob 522/84; Decision of 27 February 1985.

4 Ob 506/74; HG Vienna 3R 178/73, Decision of 5 March 1974.

8 Ob 167/67, Decision of June 27, 1967; 4 Ob 506/74.

8 Ob 71/70; LGZ Vienna 44R 542/69, Decision of April 7, 1970. 


\section{Germany}

BGH 107, 104; XI ZR 91/88 (1989).

BGH, 20.12.1955 - I ZR 171/55 (1955).

BGHZ 35, 363 (1961).

Dierig, RGZ 91, 350 (1917).

Fraulein G. Sch. case, RG vom. 29 Nov. 1898, D. $4098 / 98$ VIII 814.5

Graf Zeppelin, RGZ 74, 308; case No. 688/09, (1910).

LG Hamburg, Beschluß von 10.01.1978, (86a) Qs 68/77; NJW 1978, 958.

Nietzsche case, RGZ 69, 401; 638/07 (1908)

Otto von Bismarck case, VI. 259/99; RGZ 45, 170 (1899).

RGZ 51, 369; No. IV 50/02 (1902).

RGZ 115, 416, IV 489/26,419(1927).

II ZR 103/57 (1958).

Italy

Celentano, Petacci e al. c. Palacci, Sent. 20 Apr. 1963, n. 990; 86 Il. Foro 877.

La Corte Constituzionale, Sent. No. 51 del. 1992

Rossi e al. c. Soraya Esfandiari, Sent. 27 Mar. 1975, n. 2129; 99 Il. Foro 2896, 2905

Tirreno Asso Film c. Caruso, Sent. 22 Dec. 1956 n. 4487, 80 Il. Foro 4.

\section{Liechtenstein}

F.L. OGH 16.08.1993; 4C 170/32-23, 1 Bosch 58.

\section{Switzerland}

Banque de X. \& Cie. c. Etat de Fribourg, BGE 64 I 187 (1938).

C c. Ministère public du canton de Vaud, BGE 111 IV 74. (1985).

Caisse d'épargne de Bassetcourt c. Choffat, BGE 89 II 87. (1963).

De Vietinghoff c. de Niederhausen, BGE 44 II 319 (1918).

Demont et al. c. Conseil d'Etat du canton de Genève, BGE 100 Ia 97 (1974.)

E g. X Bank Corp., BGE 120 II 118, 119; 121-123 (1994).

Konkursverwaltung der Kredit- und Verwaltungsbank Zug AG, BGE 86 III 114, (1960).

La Cause Dubois, BGE 85 III 118 (1959).

M. g. Regierungsrat des Kantons Zürich, BGE 113 Ia 1, 7 (1987).

M. g. Regierungsrat des Kantons Zürich, BGE 113 Ia 1, 8-9 (1987).

Metzler g. Philanthropische Gesellschaft Union und Mitbeteiligte, BGE 97 II 97 (1971).

N. g. Vereinigte Staaten von Amerika, Bezirksanwaltschaft Zürich und Staatsanwaltschaft des Kantons Zürich, BGE 95 I 439, 440-442; 447-448 (1969).

S. X. g. Eidgenössische Bankenkommission, BGE 125 II 83 (1998).

Schärer g. N.N., BGE 73 IV 27 (1947).

Sidler g. Litschgi, BGE 81 IV 281 (1955).

Thurgau g. Dändlicker, BGE 65 I 47 (1938).

X. g. den Regierungsrat des Kantons Y, BGE 95 I 103 (1969).

X. g. Staatsanwaltschaft und Kantonsgerichtsausschuss von Graubünden, BGE 91 I 200 (1965). 
X. und Y. g. Eidgenössische Steuerverwaltung, BGE 137 II 128 (2010).

X. und Y-Bank g. Eidgenössische Steuerverwaltung, $101 \mathrm{Ib} 160$ (1975) [note the 1973 Treaty].

Z. g. M und Kantonsgericht von Graubünden, 80 I 1 (1954). 